\title{
Extracellular Human Immunodeficiency Virus Type 1 Tat Protein Promotes Aggregation and Adhesion of Cerebellar Neurons
}

\author{
Michael J. Orsini, ${ }^{1}$ Christine M. Debouck, ${ }^{1}$ Christine L. Webb, ${ }^{2}$ and Paul G. Lysko ${ }^{2}$ \\ ${ }^{1}$ Department of Molecular Genetics and 'Department of Cardiovascular Pharmacology, SmithKline Beecham \\ Pharmaceuticals, King of Prussia, Pennsylvania 19406
}

Recombinant human immunodeficiency virus (HIV-1) Tat protein added to the culture medium of rat cerebellar neurons promoted aggregation and formation of spoke-like neurites in a dose-dependent manner. Tat proteins containing mutations in the Arg-Gly-Asp (RGD) cell adhesion motif or a deletion of the cysteine-rich domain had no effect on neuronal morphology. In contrast, a Tat protein that contained a deletion of the prolinerich domain promoted neuronal aggregation. Aggregation of neurons was inhibited by the addition of monoclonal antibodies directed against the RGD and basic domains of Tat, but not against the proline-rich domain. The same domains of Tat required to induce aggregation also mediated adhesion of neurons to Tat-coated substrates. The HIV-2 Tat protein, which lacks an RGD sequence but contains cysteine-rich and basic domains similar to HIV-1 Tat, induced aggregation and acted as a substrate for adhesion when added at higher concentrations than HIV-1 Tat. Vitronectin, fibronectin, and RGD-containing peptides did not induce morphological changes in neurons or act as substrates for adhesion. The ability of Tat to induce morphological changes and promote adhesion was independent of the ability of Tat to transactivate HIV gene expression. Our results suggest that extracellular Tat protein most likely alters neuronal morphology and mediates adhesion by acting in a manner similar to an extracellular matrix protein.

Key words: HIV-1 Tat; cerebellar granule cells; morphology; adhesion; $R G D$ sequence; transactivation
The HIV-1 Tat protein is a potent transactivator of viral transcription directed by the HIV-1 long terminal repeat (LTR). Tat function requires the binding of Tat to a sequence in the LTR known as the transacting response element (TAR) (for a review, see Gait and Karn, 1993). Tat has been demonstrated to affect both transcription initiation and elongation (reviewed in Jones and Peterlin, 1994). In addition, Tat has been shown to induce morphological changes in certain cell types, enhance cell growth, and promote adhesion. Tat protein is released from infected cells and extracellular Tat can enter neighboring cells to affect gene expression and promote cell growth (Ensoli et al., 1990; Marcuzzi et al., 1992; Ensoli et al., 1993). Tat has been shown to induce the formation of Kaposi's sarcoma-like (KS) spindle cells in vascular endothelial cells and promotes growth and adhesion of these cells (Ensoli et al., 1990; Buonaguro et al., 1994b; Albini et al., 1995; Fiorelli et al., 1995). KS cells and cells of lymphoid, epithelial and neural origin, adhere to Tat-coated substrates (Brake et al., 1990a; Barillari et al., 1993). Tat-mediated cell growth and adhesion are enhanced by exposure of cells to cytokines (Barillari et al., 1992, 1993; Albini et al., 1995). Recently, both Tat and fibronectin were reported to synergize with basic fibroblast growth factor to cause KS-like lesions in mice (Ensoli et al., 1994).

Tat contains several distinct functional domains that have been characterized by extensive mutagenesis (Kuppuswamy et al., 1989) (Fig. 1). The second exon of HIV-1 Tat encodes a highly conserved RGD sequence, proposed to mediate interaction of Tat with cell surface proteins including integrins (Brake et al., 1990a;

\footnotetext{
Received Nov. 13, 1995; revised Jan. 16, 1996; accepted Jan. 22, 1996.

This work was supported by National Cooperative Drug Discovery Group Grant 5U01-AI24845-07 from National Institutes of Health.

Correspondence should be addressed to Christine M. Debouck, Department of Molecular Genetics, P.O. Box 1539, UE0548A, King of Prussia, PA 19406-0939.

Copyright (C) 1996 Society for Neuroscience $0270-6474 / 96 / 162546-07 \$ 05.00 / 0$
}

Barillari et al., 1993; Kolson et al., 1993; Denis, 1994) and may also mediate the angiogenic and proliferative effects of Tat (Ensoli et al., 1994; Albini et al., 1995). The highly conserved cysteinerich and core domains of Tat are thought to mediate the interaction of Tat with a cellular factor(s) (Madore and Cullen, 1993). The basic, arginine-rich domain mediates binding of Tat to TAR RN $\Lambda$ (Roy et al., 1990) and has also been shown to augment or directly mediate the interaction of Tat with integrins (Barillari et al., 1993; Weeks et al., 1993).

It has previously been demonstrated that extracellular Tat promoted the aggregation and adhesion of neurons and astrocytes in a mixed rat cortical cell culture in an RGD-dependent manner (Kolson et al., 1993). Other groups have reported neurotoxic effects after injection of Tat peptides comprised of the basic domain into mouse brain (Sabatier et al., 1991; Philippon et al., 1994; Magnuson et al., 1995). In this report, we examined the effects of Tat and mutant Tat proteins on a pure population of cerebellar neurons to define the domains that mediate both morphological changes and adhesion. Our results suggest that Tat alters neuronal morphology and promotes adhesion of neurons by acting in a manner similar to an extracellular matrix protein.

\section{MATERIALS AND METHODS}

Cerebellar neuron cultures. Neurons were prepared from 8-d-old rat cerebellum as described previously (Lysko and Nambi, 1993). At this neonatal stage, cerebellar granule cells are still in the neuroblast stage, enabling them to survive and differentiate in culture while other neurons die, resulting in a cell population that is $>90 \%$ pure granule cells. After the final centrifugation for $7 \mathrm{~min}$ at $500 \times \mathrm{g}$, the cell pellet was resuspended into $\sim 200 \mathrm{ml}$ of growth medium consisting of Basal Medium Eagle with Earle's salts (Gibco, Grand Island, NY) supplemented with 2 $\mathrm{mM}$ L-glutamine, $25 \mathrm{mM} \mathrm{KCl}, 100 \mu \mathrm{g} / \mathrm{ml}$ gentamicin (Sigma, St. Louis, $\mathrm{MO}$ ), and $10 \%$ heat-inactivated defined fetal bovine serum (HyClone Laboratories, Logan, UT). Twenty-four well culture dishes (Nunc, Roskilde, Denmark) were coated with $5 \mu \mathrm{g} / \mathrm{ml}$ poly-L-lysine (PLL) (Sigma) 
HIV-1 Tat $1 \ldots$ MEPVDPRL ...EPWKHPGSQP ............... 21 $\therefore: \ldots \ldots|\quad||: \ldots: .$.$| .$ . 1 . HIV-2 Tat 1 METPLKAPESSLKSCNBPFSRTSEQDVATQBLARQGEEILSQLYRPLETC 50 HIV-1 Tat 22 CTNCYCKKCCFHCQVCFITKALGISYGRKKRRQRRRPPQGSQTHQVSLSK 71 $.||||:||:|||:||:| .|:|||:|:||||||.| . . .||$.

HIV-2 Tat 51 NNSCYCKRCCYHCQMCFLNKGLGICYERKGR. .RRRTPKKTKTHPSPTPD 98

HIV-1 Tat 72 QPTSQSRGDPTGPKE........... 86

$\ldots|\cdot||. .$.$| .$

HIV-2 Tat 99 KSISTRTGDSQPTKKQRKTVEATVETDTGPGR 130

Figure 1. Comparison of the amino acid sequences of HIV-1 and HIV-2 Tat proteins. Note that the HIV-1 Tat protein contains an RGD motif (amino acids 78-80), whereas HIV-2 Tat does not. Also note the conscrved cysteine-rich and basic domains (amino acids 22-57 of HIV-1 Tat and amino acids $54-84$ of HIV-2 Tat).

and incubated for at least $15 \mathrm{~min}$ and then removed. Cell suspensions were adjusted to $1.5 \times 10^{6}$ cells $/ \mathrm{ml}$ and plated at a seeding density of 7.5 $\times 10^{5}$ cells per well, or $0.5 \mathrm{ml}$ of cell suspension added to an additional $0.5 \mathrm{ml}$ of medium per well. Cultures were incubated at $37^{\circ} \mathrm{C}$ in $5 \% \mathrm{CO}_{2}$ at $95 \%$ humidity, and cytosine arabinoside (Sigma) was added to a final concentration of $20 \mu \mathrm{M} 20-24 \mathrm{hr}$ later to prevent replication of nonneuronal cells.

Tat proteins, peptides, and monoclonal antibodies. The purification of wild-type HIV-1 and HIV-2 Tat proteins, Tat-1 $\Delta C$ YS (amino acids 23-42 deleted), Tat-1 $\triangle$ PRO (amino acids 5-22 deleted), and Tat-1KGE (amino acids $78-80$, RGD changed to KGE) proteins will be described in detail elsewhere (M. Orsini, G. Mavankal, L. Garcia-Martinez, R. Gaynor, and C. Debouck, unpublished observations). Briefly, Tat was expressed in Escherichia coli from a lambda $\mathrm{P}_{\mathrm{L}}$-based expression vector using induction with nalidixic acid (Aldovini et al., 1986). The cells were lysed in 50 mM Tris, $\mathrm{pH} 8.0,1 \mathrm{M} \mathrm{MgCl}_{2}$ and the supernatant was acidified to $\mathrm{pH} 3.0$ with $1 \mathrm{M} \mathrm{HCl}$. After centrifugation, the resulting supernatant was neutralized with $1.5 \mathrm{M}$ Tris, $\mathrm{pH} 9.0$, and made $40 \%$ in $\left(\mathrm{NH}_{4}\right)_{2} \mathrm{SO}_{4}$ by addition of a saturated solution of ammonium sulfate. The resulting precipitate was dialyzed to remove salt, and Tat was purified by FPLC on Mono-S (Pharmacia, Uppsala, Sweden). The purity of Tat was estimated to be $>95 \%$ by Coomassie staining. To lower the salt concentration, Tat was chromatographed on a Superdex-75 gel filtration column (Pharmacia) in $50 \mathrm{~mm}$ Tris, pH 8.0, $150 \mathrm{~mm} \mathrm{NaCl}, 10 \%$ glycerol. Tat-containing fractions were identified by SDS-PAGE and Coomassie staining, pooled, and frozen at $-70^{\circ} \mathrm{C}$. Murine monoclonal antibodies were purified from ascites fluid by Protein-G affinity chromatography using a MAPS-II kit (Bio-Rad Laboratories, Melville, NY) according to the manufacturer's instructions. The antibodies used were of the $\mathrm{IgG}$ subtype and were directed against the HIV-1 Pr55 gag protein (mAb 16), Tat-1 RGD sequence (mAb 9), Tat-1 amino acids 4-12 (mAb 3), and Tat-1 amino acids 53-61 (mAb 2). These epitope assignments were determined by Western blot analysis of Tat deletion proteins and Pepscan analysis as described previously (Brake et al., 1990b). The peptides GRGDSPK and GRGESPK, purified fibronectin and purified vitronectin were purchased from GIBCO-BRL (Gaithersburg, MD). Protein or peptides were added directly to $1 \mathrm{ml}$ of the cell medium at the indicated time after neurons were seeded on PLL-coated dishes.

Analysis of neuronal cultures. Neurons were examined by phase-contrast microscopy on the indicated day after addition of the different proteins or peptides. After photomicroscopy, neurons were enumerated by counting cell nuclei after washing wells twice with $1 \mathrm{ml}$ of buffer and lysing neurons in $1 \mathrm{ml}$ of ISOTON II by the addition of 2 drops of ZAP-OGLOBIN II (both from Coulter Diagnostics, Hialeah, FL). Well contents were removed into a total of $10 \mathrm{ml}$ of ISOTON II and counted in a Coulter counter model ZM, at a lower threshold setting of 15 and an attenuation of 2. To examine the ability of neurons to adhere to various substrates, 24-well dishes were coated with microgram amounts (exact amounts are given in the figure captions) of recombinant Tat proteins or commercially available vitronectin, fibronectin or peptides by adding microliter amounts to the wells together with $50 \mu \mathrm{l}$ of sterile saline solution to evenly cover the wells. After at least $30 \mathrm{~min}$, neurons were added to the dishes as described above and then examined on the indicated day after plating for adhesion and morphological appearance. The number of cells attached was determined as described above.

Tat transactivation assay. Purified Tat and mutant Tat proteins were dissolved in Dulbecco's modified Eagle medium containing $100 \mu \mathrm{M}$ chloroquine. HeLa cells that contained an integrated HIV-1 LTR driving expression of the bacterial CAT gene (Valerie et al., 1988) were exposed to Tat protein for $5 \mathrm{hr}$. The cells were then washed and DMEM containing $10 \%$ fetal bovine serum was added. Cells were harvested at $65 \mathrm{hr}$ after addition of Tat protein and CAT activity was determined as described previously (Gorman et al., 1982).

\section{RESULTS}

We first examined the response of rat cerebellar granule cells to increasing doses of purified Tat protein. Cerebellar neurons seeded onto PLL-coated wells were exposed to Tat $1 \mathrm{~d}$ after plating and the cells were examined $7 \mathrm{~d}$ later. Neurons aggregated in response to Tat in a dose-dependent manner, with visible aggregates of neurons beginning to form at a Tat concentration of $100-250 \mathrm{ng} / \mathrm{ml}$ (Fig. $2 A-D$ ). Most neurons were present in aggregated clumps at a Tat concentration of $1 \mu \mathrm{g} / \mathrm{ml}$. These aggregates were connected by long, thick bundles of neurites, effectively resembling "bicycle wheels and spokes." Aggregation was first detected $2 \mathrm{~d}$ after addition of Tat and progressively increased until nearly all cells were present in aggregates by $5-8 \mathrm{~d}$ of culture in vitro (DIV). The ability of Tat to effect a morphological change was lost as neurons developed in culture. As seen in Figure 2, $E$ and $F$, extensive aggregation occurred when Tat was added to
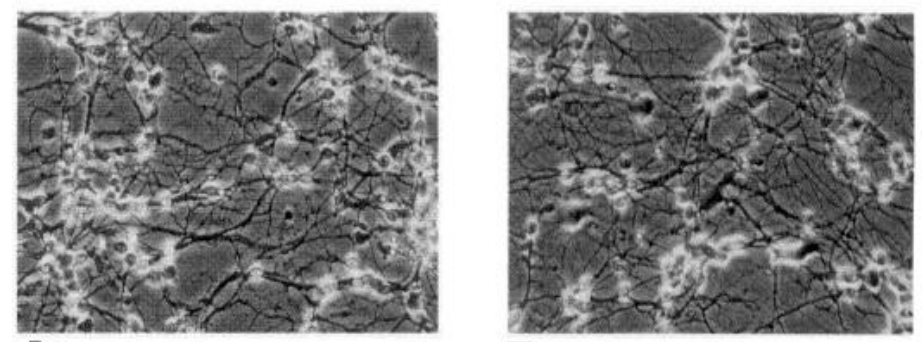

A

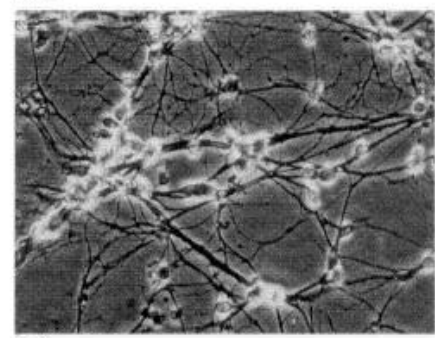

B

\section{C}
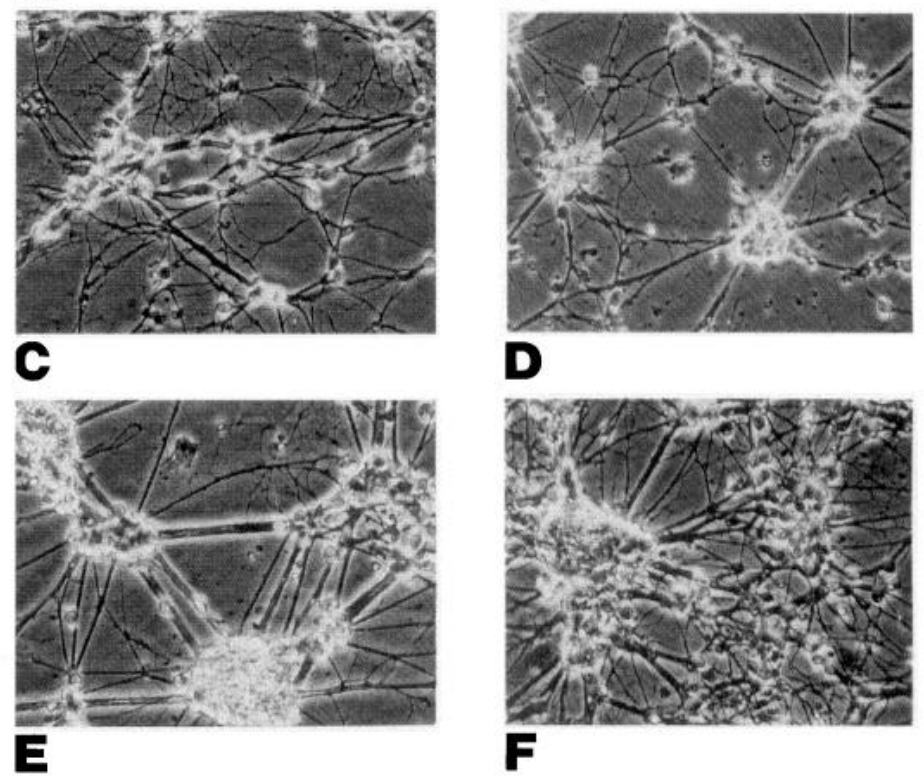

Figure 2. Effect of purified, recombinant Tat-1 protein on the morphology of cerebellar neurons. Neurons were seeded onto PLL-coated 24-well dishes as described in Materials and Methods. Tat protein was added directly to the medium of plates on the following day in vitro (1 DIV). Aggregation was recorded by phase-contrast photomicroscopy at a magnification of $300 \times . A$, Untreated neurons; $B-D$, cerebellar neurons treated from 1 to 6 DIV with 100,500 , and $1000 \mathrm{ng} / \mathrm{ml}$ wild-type Tat, respectively. $E$ and $F$ show the effect of adding $1 \mu \mathrm{g} / \mathrm{ml}$ Tat at 2 or 5 DIV, respectively, followed by examination of neurons at 8 DIV. 

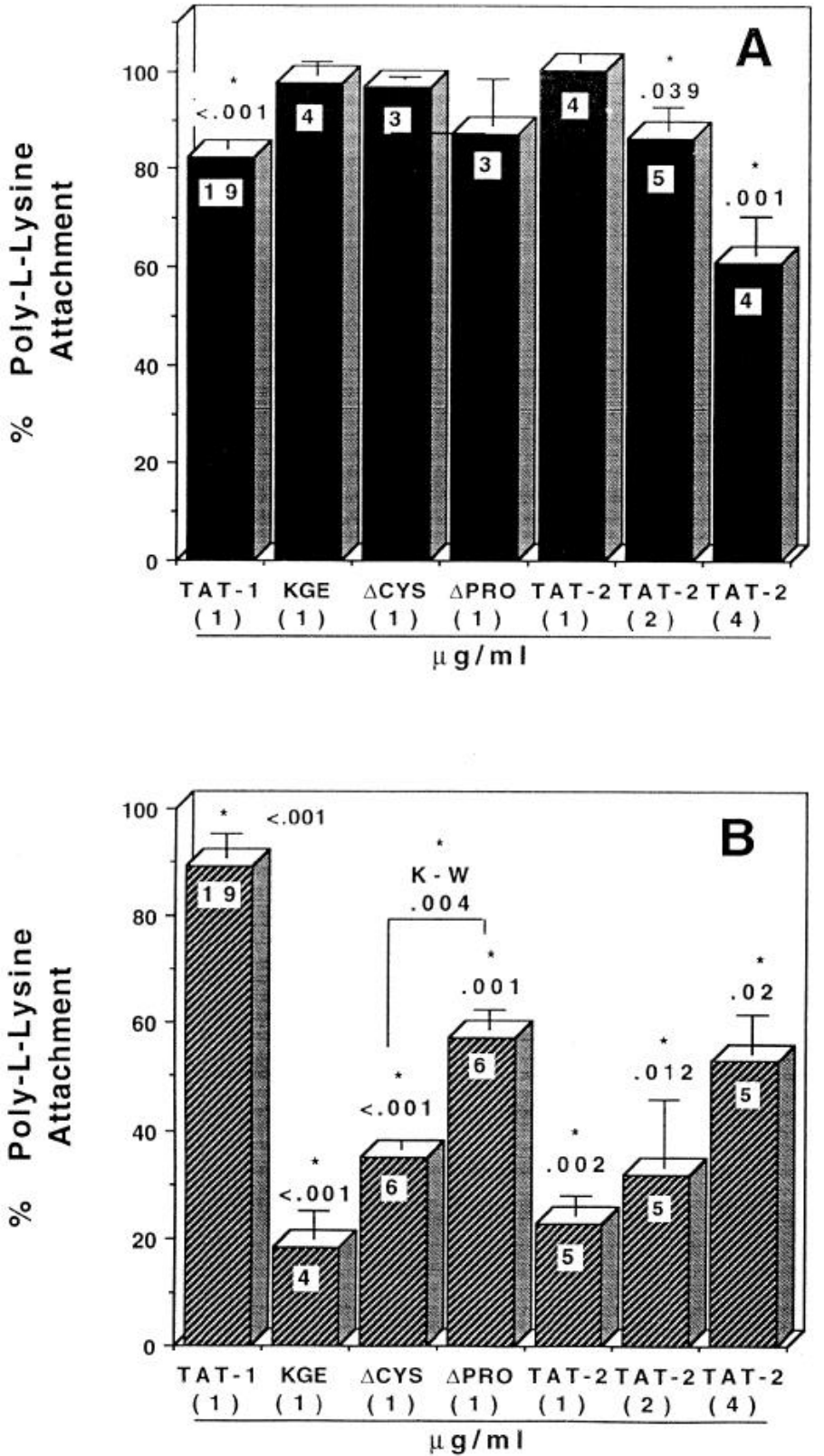

Figure 3. Analysis of Tat-mediated cell loss and Tat-mediated cell adhesion by wild-type and mutant Tat proteins. $A$, Tat-induced loss of neurons attached to poly-L-lysine. Cerebellar neurons were incubated in quadruplicate wells with wild-type Tat-1, Tat-2, or mutant Tat-1 proteins from 1-8 or 9 DIV and enumerated as described in Materials and Methods. The number of cells remaining is expressed as a percentage of the average number from untreated quadruplicate wells of neurons plated onto PLL on the same dish. $B$, Tat-mediated attachment of neurons in the absence of poly-L-lysine. The number of cells attached are expressed as a percentage of the average number of neurons attached to PLL-coated wells on the same dish. The data shown represent the mean \pm SEM from matched experiments performed in quadruplicate. Numerals in the data bars indicate the number of experiments performed. Significance is indicated by an asterisk, and was determined by paired Student's $t$ tests, except for the comparison of Tat- $1 \Delta C Y S$ and Tat- $1 \Delta \mathrm{PRO}$ in $B$, which was determined by the Kruskal-Wallis $(K-W)$ procedure.

neurons at $0,1,2$, and 4 DIV (2 DIV shown in $E$ ), but significantly less aggregation was observed at 5 DIV $(F)$, by which time neurons had extended an interwoven network of neuritic connections. During neuronal development in the presence of $1 \mu \mathrm{g} / \mathrm{ml}$ of the Tat protein, there was a $20 \%$ loss in cell number when neurons were counted after 8-9 DIV (Fig. 3A).
It was previously shown that the ability of Tat to alter the morphology of mixed rat cortical cell cultures required the RGD amino acid sequence of Tat (Kolson et al., 1993). Therefore, we examined the ability of purified Tat proteins that contained various deletions and mutations to cause aggregation of cerebellar neurons. The Tat-1KGE protein contained mutations in the RGD sequence between amino acids $78-80$ that changed this sequence to KGE (see Fig. 1). We purified two other mutant Tat proteins that contained deletions of amino acids 5-22 in the proline-rich domain (Tat-1 $\Delta$ PRO) or amino acids 23-42 in the cysteine-rich domain (Tat-1 $\Delta$ CYS). Tat-1KGE and Tat-1 $\Delta$ CYS did not cause neurons to aggregate at a concentration of $1 \mu \mathrm{g} / \mathrm{ml}$ (Fig. $4 A, B$ ) or up to $4 \mu \mathrm{g} / \mathrm{ml}$ (data not shown). In contrast, Tat- $1 \Delta$ PRO (Fig. $4 C$ ) caused neurons to aggregate to nearly the same extent as neurons treated with wild-type Tat (Fig. 4D). None of these mutant Tat proteins caused significant neuronal cell loss (Fig. $3 A$ ). We also examined the effect of the Tat protein from HIV-2 (Tat-2). Tat-2 shares considerable homology to Tat-1 in the cysteine-rich core and basic domains but does not contain an RGD sequence (Meyers et al., 1990) (see Fig. 1). The Tat-2 protein did not cause neuronal aggregation at a concentration of $1 \mu \mathrm{g} / \mathrm{ml}$ (Fig. 4E). When the concentration of Tat-2 was increased to $4 \mu \mathrm{g} / \mathrm{ml}$, neurons began to aggregate (Fig. $4 F$ ). Whereas Tat-2 was not toxic to neurons at a concentration of $1 \mu \mathrm{g} / \mathrm{ml}$, both $2 \mu \mathrm{g} / \mathrm{ml}$ and $4 \mu \mathrm{g} / \mathrm{ml}$ of Tat-2 caused a significant, dose-dependent loss of neurons (Fig. 3A). Interestingly, vitronectin and fibronectin, which mediate cell adhesion in an RGD-dependent manner, had
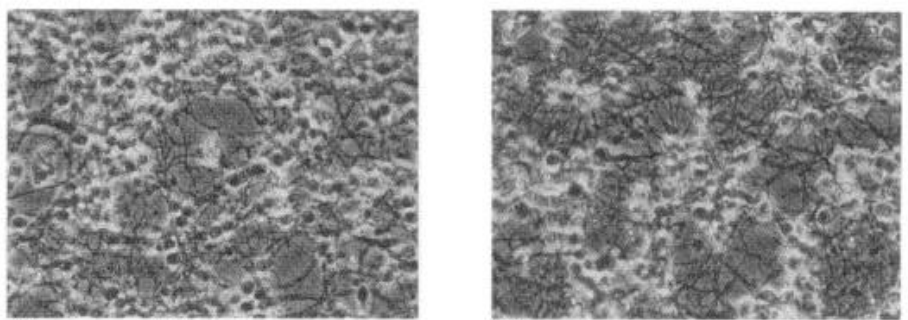

A

B

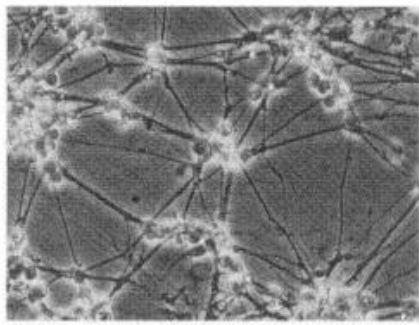

C
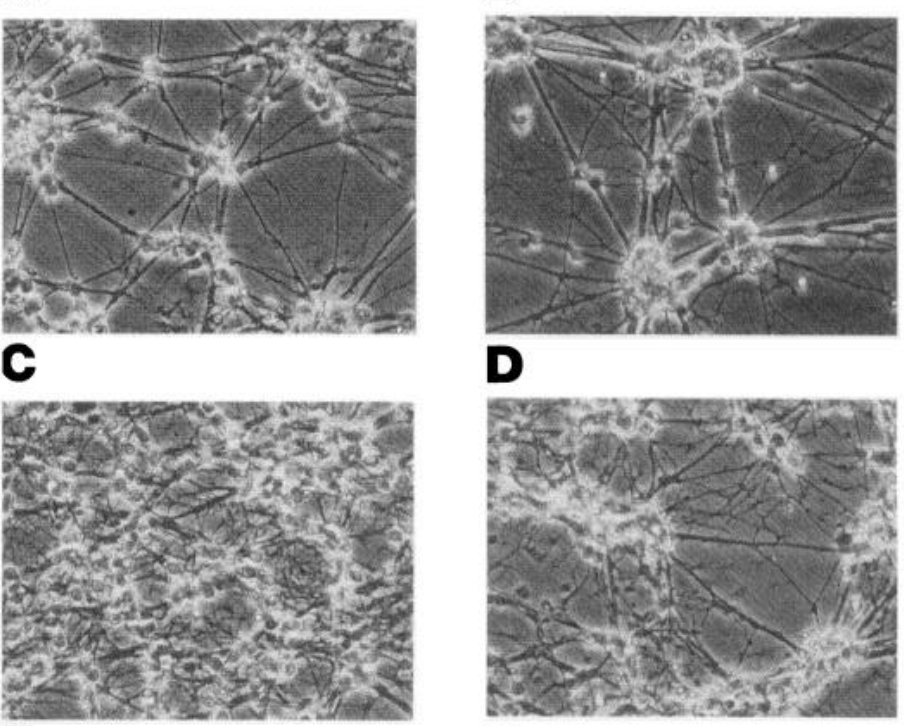

E
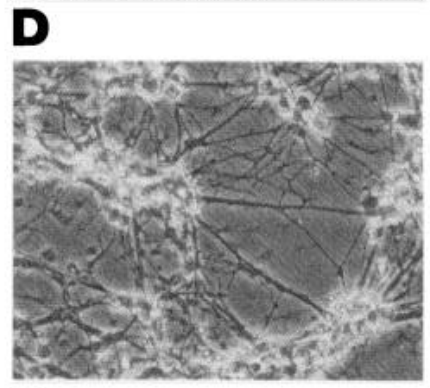

$\mathbf{F}$

Figure 4. Comparison of the effect of wild-type Tat and mutant Tat proteins on neuronal morphology. Cerebellar neurons seeded onto PLLcoated dishes were treated from 1 to 8 DIV with $1 \mu \mathrm{g} / \mathrm{ml}(A)$ Tat-1KGE, (B) Tat-1 $\Delta$ CYS, $(C)$ Tat-1 $1 \mathrm{PRO},(D)$ wild-type Tat-1, $(E)$ Tat-2, and $(F)$ $4 \mu \mathrm{g} / \mathrm{ml}$ Tat-2. Magnification, 300×. 
no effect on neuronal morphology at concentrations up to 2.5 $\mu \mathrm{g} / \mathrm{ml}$. The peptides GRGDSPK and GRGESPK also had no effect at concentrations up to $20 \mu \mathrm{g} / \mathrm{ml}$, where toxicity was noted (data not shown). These results suggest that the effects of Tat on neuronal morphology are mediated by both the basic and RGD domains, but not the proline-rich region of Tat. The cysteine-rich domain of Tat is also required and may be required to maintain the conformation of the basic and RGD domains (Bayer et al., 1995).

We have described previously the characterization of monoclonal antibodies that were developed against recombinant Tat protein (Brake et al., 1990b). These antibodies were mapped to different epitopes of Tat-1, including the proline-rich and basic domains and the RGD sequence. To further define the domains of Tat responsible for causing neuronal aggregation, we tested the ability of these antibodies to inhibit aggregation caused by Tat-1. The different antibodies were added to the cell medium together with $1 \mu \mathrm{g} / \mathrm{ml}$ of wild-type Tat- 1 protein $1 \mathrm{~d}$ after neurons were seeded onto PLL-coated dishes. As seen in Figure 5, monoclonal antibodies directed against the RGD sequence ( $\mathrm{mAb} 9$ ) and basic domain ( $\mathrm{mAb} 2$ ) of Tat-1 inhibited aggregation (Fig. $5 C, D)$. mAb 9 inhibited aggregation to a greater degree than $\mathrm{mAb} 2$. In con-
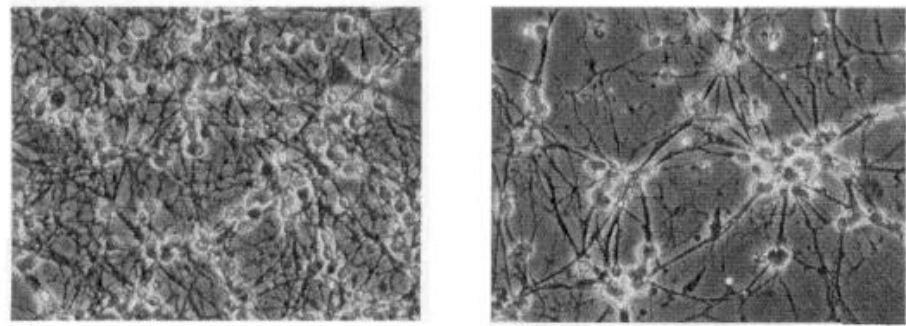

A
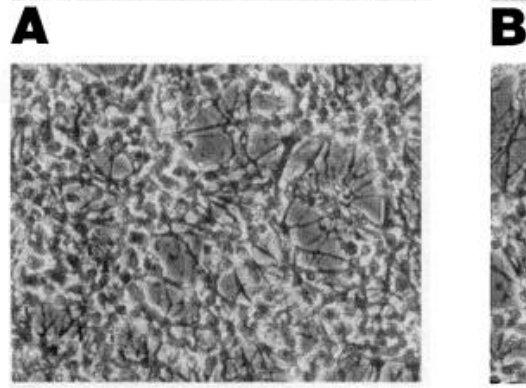

B

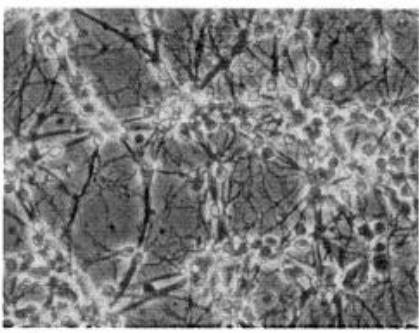

C

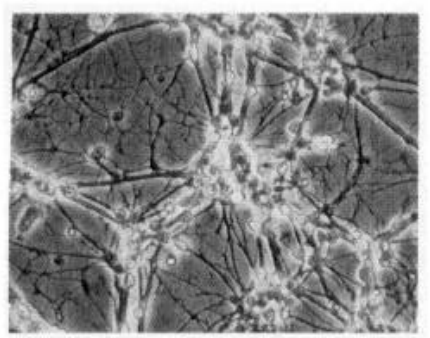

E
D

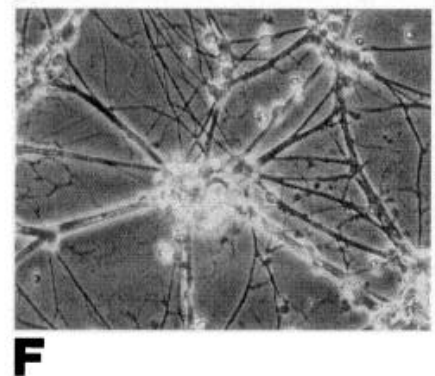

Figure 5. Ability of monoclonal anti-Tat antibodies to inhibit the effect of Tat on neuronal morphology. Cerebellar neurons seeded onto PLL-coated dishes were treated from 1 to 8 DIV with $1 \mu \mathrm{g} / \mathrm{ml}$ wild-type Tat-1 protein and $10 \mu \mathrm{g} / \mathrm{ml}$ (IgG concentration) purified anti-Tat-1 monoclonal antibodies (added $5 \mathrm{~min}$ before addition of proteins). Neurons were either left untreated $(A)$ or treated with $1 \mu \mathrm{g} / \mathrm{ml}$ Tat- 1 in the absence $(B)$ or presence of monoclonal antibodies directed against the Tat-1 RGD sequence (mAb 9, C); the Tat-1 basic domain (mAb 2, D); the Tat-1 proline-rich region (mAb 3,E); or the HIV-1 Pr55 gag protein (mAb 16, F). Magnification, $300 \times$.

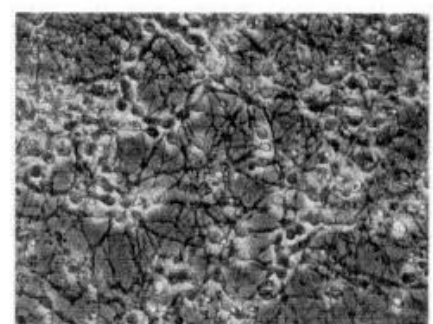

A
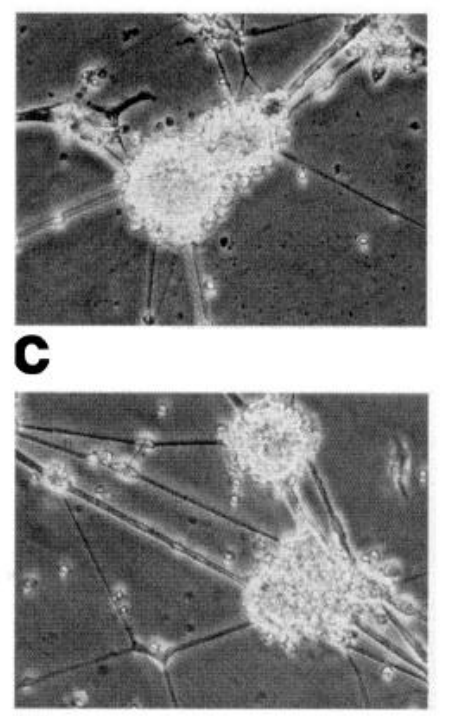

E

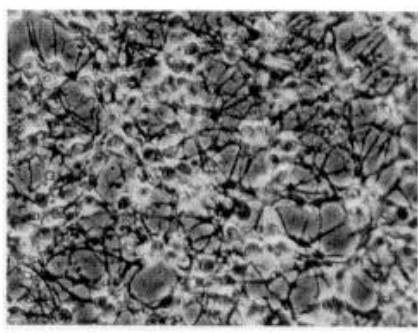

B

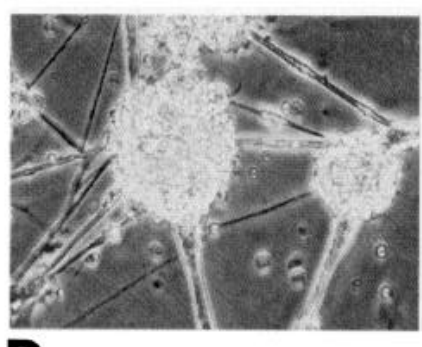

D

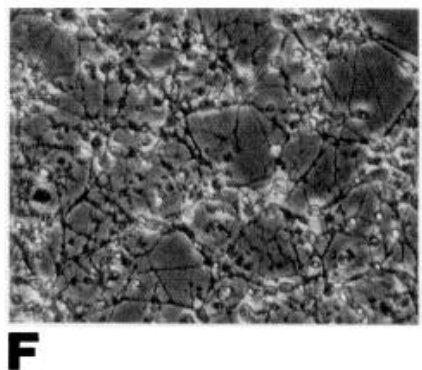

Figure 6. Analysis of the ability of Tat and mutant Tat proteins to support attachment and growth of cerebellar neurons. Dishes (24-well) were coated with $1 \mu \mathrm{g}$ of wild-type Tat- 1 or mutant Tat proteins before being seeded with neurons as described in Materials and Methods. Neurons were examined after 8 DIV. Wells were coated with $(A)$ wild-type Tat-1, $(B)$ Tat-1 $\Delta$ PRO, $(C)$ Tat-1KGE, $(D)$ Tat-1 $\Delta C Y S,(E)$ Tat-2, or $(F)$ $4 \mu \mathrm{g}$ of Tat-2. Magnification, $300 \times$.

trast, a monoclonal antibody directed against the proline-rich region of Tat-1 (mAb 3) and a control antibody directed against the HIV-1 Pr55 gag protein (mAb 16) did not inhibit Tatmediated aggregation of neurons (Fig. 5E,F). Thus, antibodies directed against regions of Tat-1 that mediate aggregation (i.e., the RGD and basic domains) also inhibit aggregation.

Tat-1 has been shown to mediate the adhesion of lymphoid, muscle, epithelial, and neural cells through the interaction of its RGD and basic regions with integrins on the cell surface (Brake et al., 1990a; Barillari et al., 1993; Kolson et al., 1993; Vogel et al., 1993; Weeks et al., 1993). Therefore, we examined the ability of neurons to adhere to dishes that were coated with wild-type and mutant Tat proteins. Wild-type Tat- 1 protein and Tat-1 $\Delta$ PRO both served as substrates on which neurons attached and proliferated (Fig. 6A,B). Morphologically, the neurons appeared identical to neurons that were seeded onto PLL-coated dishes. However, fewer neurons attached as compared to matched controls seeded onto PLL (Fig. 3B). In contrast, neurons were unable to attach and proliferate on dishes coated with Tat-1KGE or Tat$1 \Delta$ CYS (Figs. $6 C, D, 3 B$ ). As shown in Figure $3 B$, significantly more neurons attached to Tat- $1 \Delta \mathrm{PRO}$-coated wells (which promoted neuronal aggregation) than to Tat-1 $\Delta \mathrm{CYS}$ (which did not promote aggregation). Low concentrations $(1 \mu \mathrm{g})$ of Tat-2 protein also failed to support adhesion (Fig. $6 E$ ), but neurons did adhere in a dose-dependent manner to dishes that were coated with 
higher concentrations $(2-4 \mu \mathrm{g})$ of Tat-2 (Figs. $6 F, 3 B$ ). Neurons attached to dishes coated with $4 \mu \mathrm{g}$ of Tat-2 appeared morphologically similar to those attached to dishes that were coated with $1 \mu \mathrm{g}$ of Tat-1, although fewer neurons attached to Tat-2-coated wells (Fig. $3 B$ ). These results suggest that the domains of Tat- 1 and Tat-2 required to cause aggregation of neurons are identical to the domains required to support attachment and growth.

To determine whether the ability of Tat to transactivate gene expression correlated with its ability to cause aggregation and adhesion of neurons, we determined the ability of the wild-type and mutant Tat-1 proteins to activate expression of the HIV-1 LTR. The Tat-1KGE protein was previously demonstrated to transactivate the HIV-1 LTR to levels similar to wild-type Tat (Kolson et al., 1993). We have previously described a HeLa cell line that contains an integrated HIV-1 LTR that directs expression of the CAT gene (Valerie et al., 1988). Tat protein added to the medium of cells has been shown to enter cells and transactivate the LTR (Frankel and Pabo, 1988). Therefore, we tested the ability of the Tat and mutant Tat proteins to transactivate the HIV-1 LTR by adding different amounts of protein directly to the medium followed by quantitation of CAT enzymatic activity. As shown in Table 1, wild-lype Tat-1 and Tat-1KGE transactivated the HIV-1 LTR in a dose-dependent manner with equal efficiency, whereas Tat-1 $\Delta$ PRO and Tat-1 $\Delta$ CYS failed to transactivate the LTR. Because Tat- $1 \Delta$ PRO was not able to transactivate and Tat-1KGE strongly transactivated the HIV LTR, the ability of Tat to cause morphological changes and mediate adhesion appears to be independent of its ability to transactivate HIV gene expression.

\section{DISCUSSION}

In this report, we show that extracellular HIV-1 Tat protein promotes the aggregation and adhesion of rat cerebellar neurons. Tat-mediated aggregation and attachment of neurons required the cysteine-rich basic and RGD domains of Tat. The RGD motif

\section{Table 1. Transactivation of the HIV-1 LTR by wild-type and mutant} Tat proteins

\begin{tabular}{|c|c|}
\hline Protein $(\mu \mathrm{g} / \mathrm{ml})$ & $\%$ Acetylation \\
\hline 0 & 4.2 \\
\hline 0.1 Tat 1 & 14.3 \\
\hline 0.5 Tat-1 & 50.5 \\
\hline 1.0 Tat -1 & 67.2 \\
\hline 0.1 Tat-1KGE & 13.8 \\
\hline 0.5 Tat $-1 \mathrm{KGE}$ & 42.7 \\
\hline 1.0 Tat-1KGE & 63.6 \\
\hline 0.1 Tat $-1 \Delta \mathrm{PRO}$ & 1.6 \\
\hline 0.5 Tat $-1 \Delta$ PRO & 4.5 \\
\hline 1.0 Tat $-1 \Delta \mathrm{PRO}$ & 0.0 \\
\hline 5.0 Tat $-1 \Delta \mathrm{PRO}$ & 4.5 \\
\hline 0.1 Tat-1 $\Delta$ CYS & 0.0 \\
\hline 0.5 Tat- $1 \Delta \mathrm{CYS}$ & 0.0 \\
\hline 1.0 Tat $-1 \Delta \mathrm{CYS}$ & 0.0 \\
\hline 5.0 Tat $-1 \Delta \mathrm{CYS}$ & 0.0 \\
\hline
\end{tabular}

Transactivation of the HIV-1 LTR by wild-type and mutant Tat-1 proteins. The indicated amounts of wild-type or mutant Tat-1 protein were dissolved in medium containing $100 \mu \mathrm{m}$ chloroquine. Protein was added to subconfluent HeLa cells that contained an integrated copy of the HIV-1 LTR driving expression of CAT. The cells were incubated with protein for $5 \mathrm{hr}$, after which the cells were washed and the medium was replaced. Cells were harvested $65 \mathrm{hr}$ after addition of protein, and CAT activity was determined. The values shown are the mean of duplicate experiments. The average error did not exceed $5 \%$ for any value present in ECM proteins such as fibronectin and vitronectin mediates the interaction of these proteins with their cognate integrins (Pierschbacher and Ruoslahti, 1986). Both the basic and RGD-domains have been shown to mediate the interaction of Tat with integrins, resulting in adhesion of cells to Tat (Brake et al., 1990d; Barillari et al., 1993; Kolson el al., 1993; Vogel et al., 1993; Weeks et al., 1993; Denis, 1994). Antibodies directed against the $\alpha_{\mathrm{v}} \beta_{3}$ and $\alpha_{5} \beta_{1}$ integrins inhibited adhesion to Tat, suggesting that Tat interacts directly with integrins (Barillari et al., 1993; Vogel et al., 1993). Because mutation of the RGD sequence or antibodies against the RGD motif eliminated the ability of Tat to promote aggregation and adhesion of cerebellar neurons, our data further demonstrate the involvement of the RGD sequence in mediating the effects of Tat on cell adhesion and morphology.

Other domains of Tat also mediated aggregation and adhesion of neurons. An antibody directed against the Tat basic domain inhibited aggregation, but to a lesser extent than the antibody directed against the RGD sequence. HIV-2 Tat, which does not contain an RGD sequence but contains a highly homologous basic domain, mediated adhesion of neurons and promoted aggregation when used at higher concentrations. The $\alpha_{v} \beta_{5}$ integrin and a 90 $\mathrm{kDa}$ cell surface protein have both been reported to interact with the basic domain (Vogel et al., 1993; Weeks et al., 1993). Our data also support a role for the basic domain of Tat in mediating the effects of Tat on cerebellar neurons. Interestingly, deletion of the cysteine-rich region eliminated the ability of Tat to cause neuronal aggregation and adhesion. NMR analysis of Tat protein suggests that the cysteine-rich domain may stabilize the conformation of the RGD sequence (Bayer et al., 1995). In contrast, deletion of the proline-rich domain did not affect Tat-mediated aggregation or adhesion, and antibodies against this domain did not inhibit aggregation, demonstrating that this region of Tat is not required.

Several studies have demonstrated that Tat promotes morphological changes in cells. Mice transgenic for HIV-1 Tat have been shown to develop KS-like lesions (Vogel et al., 1988). Tat and fibronectin synergize with basic fibroblast growth factor to cause KS-like lesions in normal vascular endothelial cells, further suggesting that Tat interacts with integrins (Ensoli et al., 1994). Nodular lesions consisting of activated monocytes, macrophages, and astrocytes developed in the brains of mice injected with peptides comprised of the Tat basic domain (Hayman et al., 1993; Philippon et al., 1994). We have previously shown that astrocytes and neurons in mixed rat cortical cell cultures also aggregated in response to Tat in an RGD-dependent manner (Kolson et al., 1993). We found that the same domains of Tat required for adhesion of cerebellar neurons were also responsible for Tatmediated neuronal aggregation. The ability of Tat to cause aggregation diminished as the cultures matured, suggesting that Tat interfered with the ability of neurons to make productive cell-cell and cell-substrate connections. Together, these results support the notion that Tat may act by competing with an adhesion molecule(s) on neuritic growth cones for binding to extracellular matrix proteins.

Peptides comprised of the Tat basic domain have also been shown to produce neurotoxic effects when injected into mouse brain, and peptides that contained only the RGD sequence did not cause toxicity (Hayman et al., 1993; Philippon et al., 1994). The neurotoxicity of Tat peptides appears to be nonspecific, because peptides comprised of the basic domain of sheep visna virus Tat and HIV-1 rev, which possess considerable homology to the Tat basic domain, were also reported to be neurotoxic (Mabrouk et al., 1991). In contrast, the effect of Tat on cerebellar 
neurons does not appear to result from loss of neurons caused by toxicity of the various Tat proteins. The $20 \%$ loss of neurons that we observed in cells treated with wild-type Tat may result from washing the cells before counting. Because neurons treated with Tat aggregate, neurons may be lost during washing because they are poorly attached to PLL-coated wells. Furthermore, the basic domain was present in all of the Tat mutant proteins, yet there was no loss of neurons after exposure to Tat-1 $1 \Delta \mathrm{CYS}$, Tat-1 $1 \Delta \mathrm{PRO}$, or Tat-1KGE. Therefore, the ability of Tat to alter morphology and mediate adhesion of cerebellar neurons does not appear to ressult from toxicity.

The ability of Tat to cause morphological changes and mediate adhesion did not correlate with the ability of Tat to transactivate HIV gene expression. Tat- $1 \triangle \mathrm{PRO}$ was unable to activate LTRdirected gene expression but effectively promoted aggregation and adhesion of neurons. In contrast, Tat-1KGE strongly transactivated the HIV-1 LTR but was unable to cause neuronal aggregation and adhesion. Extracellular Tat has been shown to transactivate the HIV-1 LTR in neural cells (Kolson et al., 1994) and activates expression of certain cellular genes in a TARindependent manner. Expression of TNF- $\alpha$ and TNF- $\beta$ has been shown to be increased by Tat in lymphoid cells (Buonaguro el al., 1994a). In astrocytes, TAR-independent transactivation by Tat is mediated by NF- $\kappa$ B sequences in the HIV-1 LTR (Taylor et al., 1992b, 1995). TAR-independent transactivation by Tat did not require the presence of the basic domain but did require the amino-terminal "activation" domain of Tat (Taylor et al., 1993). Tat-1 $\triangle$ PRO contains a substantial deletion in this domain and lacks the same residues identified as critical for TAR-independent transactivation in astrocytes. Therefore, it is unlikely that neuronal aggregation and adhesion are caused by $T \Lambda R$-independent transactivation of a cellular gene(s) by Tat.

Mature neurons have not yet been reported to be susceptible to HIV infection; however, immature neurons and neural tumor cell lines can sustain low levels of HIV replication (Truckenmiller et al., 1993; Ensoli et al., 1995). The pathological effects of HIV infection in the brain likely result from indirect effects of HIV gene products and cytokines released by other cells within the CNS that are more permissive for HIV infection (Atwood et al., 1993). Monocytes, macrophages, glial cells, and astrocytes are the major targets of HIV-1 infection in the brain (Gabuzda et al., 1986; Koenig et al., 1986; Wiley et al., 1986; Kure et al., 1991). HIV proteins such as gp120 are released by infected cells and are neurotoxic or mediate the release of neurotoxins (Giulian et al., 1993; Toggas et al., 1994). Cytokines released by HIV-infected cells in the brain (Gallo et al., 1989; Tyor et al., 1992) have been shown to be neurotoxic both alone and in combination with cell-to-cell interactions (Giulian et al., 1990; Merrill and Chen, 1991; Genis et al., 1992; Tardieu et al., 1992). Cytokines also have been reported to upregulate HIV gene expression in various cell types found in the brain (Tornatore et al., 1991; Swingler et al., 1992; Atwood et al., 1994), which may increase expression of Tat. Although the concentration of Tat in vivo during HIV infection is not known, only nanomolar amounts are required to promote cell proliferation (Ensoli et al., 1993). Because Tat-mediated aggregation of cerebellar neurons is more pronounced in developing neuronal cultures, it is possible that Tat may preferentially affect the developing brain or neurons seeking to remodel after traumatic insult to their accessory cells. Recently, it was shown that injected RGD-containing peptides affected the migration of neurons in developing cerebral cortex in chick embryos (Hatta et al., 1994). It is possible that Tat may interfere with neuronal devel- opment and remodeling by competing with extracellular matrix proteins. The ability of growth factors and cytokines to augment the response of endothelial cells to Tat has been proposed to result from their ability to increase the expression of integrins with which Tat may interact (Taylor et al., 1992a; Barillari et al., 1993; Ensoli et al., 1994; Fiorelli et al., 1995). It is possible that the effects of Tat on cerebellar and cortical neurons may be mediated by a similar mechanism. We are currently exploring whether growth factors or cytokines affect Tat-mediated adhesion and aggregation of neurons and whether Tat directly or indirectly affects cytokine expression. We are also attempting to characterize the specific molecule(s) with which Tat may interact. These studies will hopefully lead to a better understanding of the roles of Tat and cellular factors in the pathogenesis of HIV infection in the brain.

\section{REFERENCES}

Albini A, Barillari G, Benelli R, Gallo RC, Ensoli B (1995) Angiogenic properties of human immunodeficiency virus type 1 Tat protein. Proc Natl Acad Sci USA 92:4838-4842.

Aldovini A, Debouck C, Feinberg MB, Rosenberg M, Arya SK, WongStaal F (1986) Synthesis of the complete trans-activation gene product of human T-lymphotrophic virus type III in Escherichia coli: demonstration of immunogenicity in vivo and expression in vitro. Proc Natl Acad Sci USA 83:6672-6676.

Atwood WJ, Berger JR, Kaderman R, Tornatore CS, Major EO (1993) Human immunodeficiency virus type 1 infection of the brain. Clin Microbiol Rev 6:339-366.

Atwood WJ, Tornatore CS, Traub R, Conant K, Drew PD, Major EO (1994) Stimulation of HIV type 1 gene expression and induction of NF-kappa B (p50/p65)-binding activity in tumor necrosis factor alphatreated human fetal glial cells. AIDS Res Hum Retroviruses 10:1207-1211.

Barillari G, Buonaguro L, Fiorelli V, Hoffman J, Michaels F, Gallo RC, Ensoli B (1992) Effects of cytokines from activated immune cells on vascular cell growth and HIV-1 gene expression. J Immunol 149: 3727-3734.

Barillari G, Gendelman R, Gallo RC, Ensoli B (1993) The Tat protein of human immunodeficiency virus type 1, a growth factor for AIDS Kaposi sarcoma and cytokine-activated vascular cells, induces adhesion of the same cell types by using integrin receptors recognizing the RGD amino acid sequence. Proc Natl Acad Sci USA 90:7941-7945.

Bayer P, Kraft M, Ejchart A, Westendorp M, Frank R, Rösch P (1995) Structural studies of HIV-1 Tat protein. J Mol Biol 247:529-535

Brake DA, Debouck C, Biesecker G (1990a) Identification of an ArgGly-Asp (RGD) cell adhesion site in human immunodeficiency virus type 1 transactivating protein, tat. J Cell Biol 111:1275-1281.

Brake DA, Goudsmit J, Krone W, Schammel P, Appelby N, Meloen RH, Debouck C (1990b) Characterization of murine monoclonal antibodies to the Tat protcin from human immunodeficiency virus type 1 . J Virol 64:962-965.

Buonaguro L, Buonaguro FM, Giraldo G, Ensoli B (1994a) The human immunodeficiency virus type 1 l'at protein transactivates tumor necrosis factor beta gene expression through a TAR-like structure. J Virol 68:2677-2682.

Buonaguro L, Buonaguro FM, Tornesello ML, Beth GE, Del GE, Ensoli B, Giraldo G (1994b) Role of HIV-1 Tat in the pathogenesis of AIDSassociated Kaposi's sarcoma. Antibiot Chemother 46:62-72.

Denis M (1994) Tat protein from HIV-1 binds to Mycobacterium avium via a bacterial integrin. J Immunol 153:2072-2081.

Ensoli B, Barillari G, Salahuddin SZ, Gallo RC, Wong-Staal F (1990) Tat protein of HIV-1 stimulates growth of cells derived from Kaposi's sarcoma lesions of AIDS patients. Nature 345:84-86.

Ensoli B, Buonaguro L, Barillari G, Fiorelli V, Gendelman R, Morgan RA, Wingfield P, Gallo RC (1993) Release, uptake and effects of extracellular human immunodeficiency virus type 1 Tat protein on cell growth and viral transactivation. J Virol 67:277-287.

Ensoli B, Gendelman R, Markham P, Fiorelli V, Colombini S, Raffeld M, Cafaro A, Chang H-K, Brady J, Gallo RC (1994) Synergy between basic fibroblast growth factor and HIV-1 Tat protein in induction of Kaposi's sarcoma. Nature 371:674-680. 
Ensoli F, Cafaro A, Fiorelli V, Vannelli B, Ensoli B, Thiele CJ (1995) HIV-1 infection of primary human neuroblasts. Virology 210:221-225.

Fiorelli V, Gendelman R, Samaniego F, Markham PD, Ensoli B (1995) Cytokines from activated $T$ cells induce normal endothelial cells to acquire the phenotypic and functional features of AIDS-Kaposi's sarcoma spindle cells. J Clin Invest 95:1723-1734.

Frankel AD, Pabo CO (1988) Cellular uptake of the Tat protein from human immunodeficiency virus. Cell 55:1189-1193.

Gabuzda DII, IIo DD, De La Monte SM, IIirsch MS, Rota TR, Sobel RA (1986) Immunohistochemical identification of HTLV-III antigen in brains of patients with AIDS. Ann Neurol 20:289-295.

Gait MJ, Karn J (1993) RNA recognition by the human immunodeficiency virus Tat and Rev proteins. Trends Biochem Sci 18:255-259.

Gallo P, Frei K, Rordorf C, Lazdins J, Tavolata B, Fontana A (1989) Human immunodeficiency virus type 1 (HIV-1) infection of the central nervous system: an evaluation of cytokines in cerebrospinal fluid. J Neuroimmunol 23:100-116.

Genis P, Jett M, Bernton EW, Boyle T, Gelbard HA, Dzenko K, Keane RW, Resnick L, Mizrachi Y, Volsky DJ, Epstein LG, Gendelman HE (1992) Cytokines and arachidonic metabolites produced during human immunodeficiency virus (HIV) infected macrophage-astroglia interactions: implications for the neuropathogenesis of HIV disease. J Exp Med 176:1703-1718.

Giulian D, Vaca K, Noonan CA (1990) Secretion of neurotoxins by mononuclear phagocytes infected by HIV-1. Science 250:1593-1597.

Giulian D, Wendt E, Vaca K, Noonan CA (1993) The envelope glycoprotein of human immunodeficiency virus type 1 stimulates release of neurotoxins from monocytes. Proc Natl Acad Sci USA 90:2769-2773.

Gorman CM, Moffat LF, Howard BH (1982) Recombinant genomes which express chloramphenicol acetyltransferase in mammalian cells. Mol Cell Biol 2:1044-1051.

Hatta T, Tanaka O, Otani H (1994) Contribution of RGD sequence to neuronal migration in developing cerebral cortex. NeuroReport 5:2261-2264.

Hayman M, Arbuthnott G, Harkiss G, Brace H, Filippi P, Philippon V, Thomson D, Vigne R, Wright A (1993) Neurotoxicity of peptide analogues of the transactivating protein Tat from maedi-visna virus and human immunodeficiency virus. Neuroscience 53:1-6.

Jones KA, Peterlin BM (1994) Control of RNA initiation and elongation at the HIV-1 promoter. Annu Rev Biochem 63:717-743.

Koenig S, Gendelman HE, Orenstein JM, DalCanto MC, Pezeshkpour GH, Yungbluth M, Janotta F, Aksamit A, Martin MA, Fauci AS (1986) Detection of AIDS virus in macrophages in brain tissue from AIDS patients with encephalopathy. Science 233:1089-1093.

Kolson D, Buchhalter J, Collman R. Hellmig B, Farrell C, Debouck C, Gonzalez-Scarano F (1993) HIV-1 Tat alters normal organization of neurons and astrocytes in primary rodent brain cell cultures: RGD sequence dependence. AIDS Res Hum Retroviruses 9:677-685.

Kolson DL, Collman R, Hrin R, Balliet JW, Laughlin M, McGann KA, Debouck C, Gonzalez-Scarano F (1994) Human immunodeficiency virus type 1 Tat activity in human neuronal cells: uptake and transactivation. J Gen Virol 75:1927-1934.

Kuppuswamy M, Subramanian T, Srinivasan A, Chinnadurai G (1989) Multiple functional domains of Tat, the trans-activator of HIV-1, defined by mutational analysis. Nucleic Acids Res 17:3551-3561.

Kure K, Llena JF, Lyman WD (1991) Human immunodeficiency virus-1 infection of the nervous system: an autopsy study of 268 adult, pediatric and fetal brains. Hum Pathol 22:700-710.

Lysko PG, Nambi P (1993) Endothelin receptors in neural systems. Methods Neurosci 11:186-198.

Mabrouk K, Van Reitschoten J, Vives E, Darbon H, Rochat H, Sabatier JM (1991) Lethal neurotoxicity in mice of the basic domains of the HIV and SIV Rev proteins. Study of these regions by circular dichroism. FEBS Lett 289:13-17.

Madore SJ, Cullen BR (1993) Genetic analysis of the cofactor requirement for human immunodeficiency virus type 1 Tat function. $\mathbf{J}$ Virol 67:3703-3711.

Magnuson DSK, Knudson BE, Geiger JD, Brownstone RM, Nath A (1995) Human immunodeficiency virus type 1 Tat activates non- $N$ methyl-D-aspartate excitatory amino acid receptors and causes neurotoxicity. Ann Neurol 37:373-380.

Marcuzzi A, Lowy I, Weinberger OK (1992) Transcellular activation of the human immunodeficiency virus type I long terminal repeat in $\mathrm{T}$ lymphocytes requires CD4-gp120 binding. J Virol 66:4536-4539.
Merrill JE, Chen ISY (1991) HIV-1, macrophages, glial cells and cytokines in AIDS nervous system disease. FASEB J 5:2391-2397.

Meyers G, Josephs SF, Berzofsky JA, Rabson AB, Smith TF, Wong-Staal F (1990) Human retroviruses and AIDS. Los Alamos, NM: Los Alamos National Laboratory.

Philippon V, Vellutini C, Gambarelli D, Harkiss G, Arbuthnott G, Metzger D, Roubin R, Filippi P (1994) The basic domain of the lentiviral Tat protein is responsible for damages in mouse brain: involvement of cytokines. Virology 205:519-529.

Pierschbacher M, Ruoslahti E (1986) Arg-Gly-Asp: a versatile cell recognition signal. Cell 44:517-518.

Roy S, Delling U, Chen CH, Rosen CA, Sonenberg N (1990) A bulge structure in HIV-1 TAR RNA is required for Tat binding and Tatmediated trans-activation. Genes Dev 4:1365-1373.

Sabatier J-M, Vives E, Mabrouk K, Benjouad A, Rouchat H, Duval A, Hue B, Bahraoui E (1991) Evidence for neurotoxic activity of Tat from human immunodeficiency virus type 1. J Virol 65:961-967.

Swingler S, Easton A, Morris A (1992) Cytokine augmentation of HIV-1 LTR-driven gene expression in neural cells. Aids Res Hum Retroviruses 8:487-493.

Tardieu M, Hery C, Peudeiner S, Boespflug O, Montaigner L (1992) Human immunodeficiency virus type 1-infected monucytic cells can destroy human neural cells after cell-to-cell contact. Ann Neurol 32:11-17.

Taylor JP, Cupp C, Diaz A, Chowdhury M, Khalili K, Jimenez SA, Amini S (1992a) Activation of expression of genes coding for extracellular matrix proteins in Tat-producing glioblastoma cells. Proc Natl Acad Sci USA 89:9617-9621.

Taylor JP, Pomerantz R, Bagasra O, Chowdhury M, Rappaport J, Khalili K, Amini S (1992b) TAR-independent transactivation by Tat in cells derived from the CNS: a novel mechanism of HIV-1 gene regulation. EMBO J 11:3395-3403.

I'aylor JP, Kundu M, Khalili K (1993) TAR-independent activation of HIV-1 requires the activation domain but not the RNA binding domain of Tat. Virology 195:780-785.

Taylor JP, Pomerantz RJ, Oakes JW, Khalili K, Amini S (1995) A CNSenriched factor that binds to NF-kappa $B$ and is required for interaction with HIV 1 Tat. Oncogene 10:395-400.

Toggas SM, Masliah E, Rockenstein EM, Rall GF, Abraham CR, Mucke L (1994) Central nervous system damage produced by expression of the HIV-1 coat protein gpl2U in transgenic mice. Nature $367: 188-193$

Tornatore C, Nath A, Amemiya K, Major EO (1991) Persistent human immunodeficiency type 1 infection in human fetal glial cells reactivated by $\mathrm{T}$-cell factors or the cytokines tumor necrosis factor alpha and interleukin-1 beta. J Virol 65:6094-6100.

Truckenmiller ME, Kulaga H, Coggiano M, Wyatt R, Snyder SH, Sweetnam PM (1993) Human cortical neuronal cell line: a model for HIV-1 infection in an immature neuronal system. Aids Res Hum Retroviruses 9:445-453.

Tyor WR, Glass JD, Griffin JW, Becker PS (1992) Cytokine expression in the brain during the acquired immune deficiency syndrome. Ann Neurol 31:349-360.

Valerie K, Delers A, Bruck C, Thiriart C, Rosenberg H, Debouck C, Rosenberg M (1988) Activation of human immunodeficiency virus type 1 by DNA damage in human cells. Nature 333:78-81.

Vogel J, Hinrichs SH, Reynolds RK, Luciw PA, Jay G (1988) The HIV Tat gene induces dermal lesions resembling Kaposi's sarcoma in transgenic mice. Nature 335:606-611.

Vogel B, Lee S-J, Hildebrand A, Craig W, Pierschbacher MD, Wong-Staal F, Ruoslahti E (1993) A novel integrin specificity exemplified by binding of the $\alpha v \beta 5$ integrin to the basic domain of the HIV Tat protein and vitronectin. J Cell Biol 121:461-468.

Weeks BS, Desai K, Loewenstein PM, Klotman ME, Klotman PE, Green M, Kleinman HK (1993) Identification of a novel cell attachment domain in the HIV-1 Tat protein and its $90 \mathrm{kDa}$ cell surface binding protein. J Biol Chem 268:5279-5284.

Wiley CA, Schrier RD, Nelson JA, Lampert PW, Oldstone MBA (1986) Cellular localization of human immunodeficiency virus infection within the brains of acquired immune deficiency syndrome patients. Proc Natl Acad Sci USA 83:7089-7093. 